\title{
Treatment of Hyperglycaemia in Type 2 Diabetic Patients in a Primary Care Population Database in a Mediterranean Area (Catalonia, Spain)
}

Manel Mata-Cases ${ }^{1,2 *}$, Dídac Mauricio ${ }^{2,3}$, Irene Vinagre ${ }^{4}$, Rosa Morros ${ }^{2,5}$, Eduard Hermosilla ${ }^{2}$, Francesc Fina ${ }^{2,6}$, Magdalena Rosell-Murphy², Conxa Castell ${ }^{7}$, Josep Franch-Nadal' ${ }^{2,8}$, Bonaventura Bolíbar ${ }^{2,5}$

${ }^{1}$ Primary Health Care Center La Mina, Gerencia d'Ambit d'Atencio Primaria Barcelona Ciutat, Institut Catala de la Salut, Barcelona, Spain

${ }^{2}$ Institut Universitari d'Investigació en Atenció Primària Jordi Gol (IDIAP Jordi Gol), Research Suport Unit of Barcelona, Barcelona, Spain

${ }^{3}$ Servei d'Endocrinologia i Nutrició. Hospital Germans Trias i Pujol. Badalona (Barcelona)

${ }^{4}$ Department of Endocrinology \& Nutrition, Diabetes Unit, Hospital Clinic, University of Barcelona, Barcelona, Spain

${ }^{5}$ Universitat Autònoma de Barcelona, Bellaterra (Cerdanyola del Vallès), Spain

${ }^{6}$ Institut Catala de la Salut, Barcelona, Spain

${ }^{7}$ Public Health Agency of Catalonia, Barcelona, Spain

${ }^{8}$ Primary Health Care Center Raval Sud, Institut Catala de la Salut, Barcelona, Spain

\begin{abstract}
Aim: To analyse glycaemic control and antihyperglycaemic treatment in patients with varying duration of type 2 diabetes in a population-based database.

Methods: A cross-sectional survey of 286,791 patients with type 2 diabetes registered in the primary care centres of the Catalan Health Institute (Catalonia, Spain) in 2009. We analysed the effects of types of treatment, diabetes duration and renal function on glycaemic control, adjusting for other clinical variables.

Results: Twenty-four percent of patients were treated with lifestyle changes only, $35.5 \%$ with oral glucoselowering monotherapy, $21 \%$ with oral combinations and $17.7 \%$ with insulin (alone or in combination). Insulin was more frequently used in patients with longer duration of diabetes or severe renal impairment. Fifty-six percent of patients achieved the optimal target of $\mathrm{HbA} 1 \mathrm{c} \leq 7 \%(\leq 53 \mathrm{mmol} / \mathrm{mol})$, a result more frequently observed in patients older than 65 , early in the course of the disease and at the lower steps of treatment $(p<0.001)$. Impaired renal function was present in $18.4 \%$ of patients. A significant number of patients with severe renal impairment were taking metformin $(16.2 \%)$ or sulfonylureas $(12.1 \%)$, which are contraindicated at this stage. Multivariable analyses confirmed that lower steps of treatment, advanced age and lesser years of diabetes duration were the variables positively related to good glycaemic control.
\end{abstract}

Conclusions: Glycaemic control deteriorates with the progression of the disease despite the treatment intensification. Impaired renal function was frequent and a remarkable proportion of these patients were taking contraindicated drugs.

Keywords: Type 2 diabetes; Pharmacological treatment; Diabetes duration; Renal impairment

\section{Introduction}

The prevalence of type 2 diabetes mellitus (T2DM) is increasing rapidly in most parts of the world, which is likely to increase the incidence of complications associated with the disease [1]. This calls for improved treatment of hyperglycaemia and other risk factors associated with T2DM to lower the risk of both micro- and macrovascular complications and their related economic costs $[2,3]$.

The currently available treatment options for hyperglycaemia, apart from lifestyle changes and weight reduction, are non-insulin glucose-lowering drugs and insulin. It is important that these agents be used optimally, frequently combining different therapeutic strategies, in order to achieve the commonly accepted glycaemic target level of $\mathrm{HbA}_{1 \mathrm{c}}<7 \%(<53 \mathrm{mmol} / \mathrm{mol})$ [4-9]. Despite scientific evidence and the publication of international [3,8,9] and national guidelines [4-7], adequate control of these patients' health remains beset with challenges. A number of observational studies performed in Spain [10-15] report a gap between recommendations and daily clinical practice.

The implementation of universal electronic medical records systems in Catalonia (Spain) allowed us to access the anonymized data of the entire diabetic population registered in the public healthcare system for our study, in contrast to previous studies based on population samples
[10-14]. Our group recently published a first report on the general aspects of the management of patients with T2DM in Catalonia (Spain) [15]. Previous publications on population registers in other countries have confirmed the relevance of these data to pharmacological treatment [16-28], especially when some cohorts have been followed to show differences in the incidence of cardiovascular disease, cancer or even mortality [21-28].

We undertook this study in order to specifically analyse the pharmacological treatment patterns in T2DM patients in Catalonia (Spain), with the primary aim to analyse glycaemic control and

${ }^{*}$ Corresponding author: Manel Mata-Cases, Primary Health Care Center La Mina, Gerencia d'Ambit d'Atencio Primaria Barcelona Ciutat, Institut Catala de la Salut, CAP La Mina. C/ Mar s/n. Sant Adrià de Besòs, 08930 Barcelona, Spain Tel: + 3493 3811593; Fax: + 3493 3812141; E-mail: manelmatacases@gmail.com

Received January 16, 2014; Accepted February 10, 2014; Published February 15,2014

Citation: Mata-Cases M, Mauricio D, Vinagre I, Morros R, Hermosilla E, et al (2014) Treatment of Hyperglycaemia in Type 2 Diabetic Patients in a Primary Care Population Database in a Mediterranean Area (Catalonia, Spain). J Diabetes Metab 5: 338. doi:10.4172/2155-6156.1000338

Copyright: (C) 2014 Mata-Cases M, et al. This is an open-access article distributed under the terms of the Creative Commons Attribution License, which permits unrestricted use, distribution, and reproduction in any medium, provided the original author and source are credited. 
antihyperglycaemic treatment in T2DM patients with varying duration of type 2 diabetes. Secondary aims were to analyse the effects of types of treatment and renal function on glycaemic control, adjusting for other clinical variables.

\section{Methods}

Catalonia, a Mediterranean region in northeastern Spain, has a public health system in which every citizen is registered with a general practitioner and a nurse in a publicly funded primary care centre. At each centre, doctors and nurses work as a team caring for the total population of a determined geographic area. All centres use the same software, called ECAP (Primary Care Clinical Station), to record their patients' clinical information. Healthcare and all diagnostic procedures are free of charge to patients. Medications were completely free for retired, severely ill or handicapped people. For other patients, glucoselowering and antihypertensive drugs were almost completely free of charge and they paid $40 \%$ for other treatments. Strips for blood glucose monitoring were provided free of charge for all patients following local guidelines.

The data in this cross-sectional study were obtained from the SIDIAP (Information System for the Development of Research in Primary Care) database of electronic medical records of all patients attending the 274 primary care practices of the Catalan Health Institute, covering a population of about 5.8 million patients $(80 \%$ of the total population for the region). SIDIAP (www.sidiap.org) started in 2006 and contains anonymized longitudinal patient information including sociodemographic characteristics, morbidity (International Classification of Diseases; ICD-10), clinical and lifestyle variables, specialist referrals, laboratory tests and treatments (prescription and corresponding pharmacy invoicing data) [29]. Clinical data before 2006 were transferred from paper-based records to electronic medical records by doctors and nurses.

All patients aged 31 to 90 years with a diagnosis of type 2 diabetes [ICD (International Classification of Diseases)-10 codes E11, E14] before 1/7/2009 were included. All variables registered at the end of 2009 were collected. Patients younger than 31 years were excluded to avoid the inclusion of type 1 diabetic patients. The following data were available for each patient: age, sex, time since diagnosis, estimated glomerular filtration rate (eGFR) using the MDRD (Modified Diet in Renal Disease) formula and standardized HbAlc values, using the most recent value of the preceding 15 months. Variables related to glycaemic control were analysed by age group $(<55,55-74$ and $\geq 75$ years-old) and by diabetes duration ( $<2$ years, $2-5$ years, $6-10$ years and $>10$ years). Data pertaining to other cardiovascular risk factors and chronic complications were also available and have been extensively described elsewhere [15].

Data on glucose-lowering medication were obtained from the drug pharmacy prescription invoices database. A subject was considered to receive glucose-lowering medication when he/she had obtained the medication to cover at least $80 \%$ of the total theoretical minimum dose needed from the first to the last prescription during 2009. Patients were considered untreated if they had not obtained any drugs. Patients were categorized as undergoing double or triple glucose-lowering therapy when (i) criteria for continuous treatment were met for each of the components and (ii) either a combination of two or three glucoselowering drugs or a fixed-dose combined medication was given at least for two months, according to the prescription drug pharmacy invoices.
This study was approved by the Ethics Committee of the Primary Health Care University Research Institute (IDIAP) Jordi Gol.

\section{Statistical methods}

Descriptive analysis consisted of summary statistics, mean and standard deviation for continuous variables, and percentages for categorical variables. Comparisons by age group, sex, diabetes duration, glycaemic-lowering step of treatment, and renal function were performed with Pearson chi-square tests for categorical variables and analysis of variance (ANOVA) for continuous variables. We applied multilevel logistic regression models (considering the primary care centres as random) to identify the factors associated with good glycaemic control (HbAlc $\leq 7 \%, \leq 53 \mathrm{mmol} / \mathrm{mol})$. Only those variables with a statistically significant effect at the 0.05 level in the univariable analyses remained in the multivariable model. Unadjusted and adjusted odds ratios (OR) and 95\% confidence intervals (95\%CI) were presented. Statistical calculations were performed using StataCorp 2009 (Stata Statistical Software: Release 11. College Station, TX: StataCorp, LP).

\section{Results}

Data from 286,791 patients were analysed regarding proportions of different glucose-lowering treatments, age groups and duration of diabetes (Table 1 and Figure 1). Treatment with diet only or oral monotherapy decreased sharply with increasing diabetes duration from $<2$ years to $>10$ years ( $37.8 \%$ to $12.7 \%$ and $43.2 \%$ to $23.5 \%$, respectively). The use of insulin therapy alone or combined with oral agents increased, from $7.5 \%$ to $34.4 \%$. As shown in Table 1 , the mean $\mathrm{HbA}_{1 c}$ value increased slightly with longer diabetes duration, especially in patients treated with insulin alone or in combination with oral agents. There was a slight decrease in mean BMI in all groups of patients with longer diabetes duration, although changes were smaller in patients treated with insulin alone. However, the frequency of obesity remained high, around $40 \%$ to $55 \%$, in all patients. Interestingly, clinical characteristics clearly differed between younger and older patients: patients under 55 years of age were more often smokers and considerably more obese. They also had higher mean $\mathrm{HbA}_{1 \mathrm{c}}$, but lesser complications.

\section{Glucose-lowering treatment}

Table 2 shows patient characteristics according to the glucoselowering step of treatment. Data on the use of specific glucose-lowering drugs by age group, sex, diabetes duration and renal function are shown in Table 3.

A quarter of all patients were managed only by lifestyle changes (24.4\%) with respect to oral glucose-lowering treatments: $46.9 \%, 22.9 \%$ and $2.8 \%$ were taking one, two and three glucose-lowering drugs, respectively. In total, $17.7 \%$ of the patients on continuous glucoselowering drug therapy received insulin, $7.7 \%$ as monotherapy, while $10 \%$ combined insulin with oral agents (Table 2). The most frequently prescribed oral drug was metformin ( $41.2 \%$ of patients) (Table 3 ), alone or in combination with other oral agents or insulin, except in patients with severely impaired renal function (eGFR $<30 \mathrm{ml} / \mathrm{min}$ ), for whom insulin was the most prescribed drug. Sulfonylureas were the second most prescribed oral drug (17.4\%), while other groups of medications were prescribed rarely $(<2.5 \%)$. Long-acting insulin analogs were the most prescribed type of insulin (44.0\%), followed by Neutral Protamine Hagedorn (NPH) insulin (27.6\%), pre-mixed insulins (23.0\%) and short-acting insulins $(5.0 \%)$. 
Citation: Mata-Cases M, Mauricio D, Vinagre I, Morros R, Hermosilla E, et al. (2014) Treatment of Hyperglycaemia in Type 2 Diabetic Patients in a Primary Care Population Database in a Mediterranean Area (Catalonia, Spain). J Diabetes Metab 5: 338. doi:10.4172/2155-6156.1000338

Page 3 of 7

\begin{tabular}{|c|c|c|c|c|c|c|c|c|}
\hline & $\begin{array}{l}\text { All patients } \\
(\mathrm{N}=286791)\end{array}$ & $\begin{array}{c}<55 \text { years } \\
N=37221\end{array}$ & $\begin{array}{c}55-74 \text { years } \\
N=153350\end{array}$ & $\begin{array}{c}\geq 75 \text { years } \\
\mathrm{N}=96320\end{array}$ & $\begin{array}{l}\leq 2 \text { years } \\
(\mathrm{N}=63061)\end{array}$ & $\begin{array}{c}\text { 3-5 years } \\
(\mathrm{N}=101848)\end{array}$ & $\begin{array}{l}6-10 \text { years } \\
(\mathrm{N}=80369)\end{array}$ & $\begin{array}{l}>10 \text { years } \\
(\mathrm{N}=41513)\end{array}$ \\
\hline Sex, $\%$ of males & 53.7 & 65.9 & 57.1 & 43.5 & 57.9 & 54.8 & 52.0 & 47.9 \\
\hline Age, mean years $\pm S D$ & $68.2 \pm 11.4$ & $48.3 \pm 4.9$ & $65.4 \pm 5.5$ & $80.3 \pm 3.9$ & $64.1 \pm 12.4$ & $67.8 \pm 11.3$ & $69.8 \pm 10.4$ & $72.4 \pm 9.3$ \\
\hline Diabetes duration, mean years \pm SD & $6.5 \pm 5.1$ & $4.3 \pm 3.2$ & $6.4 \pm 4.7$ & $7.7 \pm 5.9$ & $1.7 \pm 0.7$ & $4.6 \pm 0.8$ & $7.9 \pm 1.4$ & $16.0 \pm 5.7$ \\
\hline $\mathrm{HbA}_{1 \mathrm{c}}$, mean, $\% \pm \mathrm{SD}{ }^{\mathrm{a}}$ & $7.1 \pm 1.5$ & $7.5 \pm 1.9$ & $7.2 \pm 1.4$ & $7.0 \pm 1.3$ & $6.8 \pm 1.4$ & $7.1 \pm 1.4$ & $7.3 \pm 1.4$ & $7.5 \pm 1.5$ \\
\hline $\mathrm{HbA}_{1 \mathrm{c}}$, mean, $\mathrm{mmol} / \mathrm{mol} \pm \mathrm{SD}^{\mathrm{a}}$ & $54.6 \pm 16.0$ & $58.8 \pm 20.3$ & $54.9 \pm 15.7$ & $52.9 \pm 14.2$ & $50.9 \pm 15.6$ & $54.3 \pm 15.8$ & $56.3 \pm 15.8$ & $58.1 \pm 16.0$ \\
\hline $\mathrm{HbA} 1 \mathrm{c} \leq 7 \%(\leq 53 \mathrm{mmol} / \mathrm{mol})(\%)^{a}$ & 56.1 & 49.3 & 55.2 & 60.0 & 69.6 & 57.4 & 50.8 & 43.8 \\
\hline $\mathrm{BMI}$, mean $\mathrm{Kg} / \mathrm{m}^{2} \pm \mathrm{SD}^{\mathrm{b}}$ & $29.6 \pm 5.0$ & $30.7 \pm 5.7$ & $30.0 \pm 5.0$ & $28.6 \pm 4.6$ & $30.8 \pm 5.1$ & $29.7 \pm 5.0$ & $29.5 \pm 5.0$ & $29.1 \pm 4.1$ \\
\hline Obesity $\left(\mathrm{BMI} \geq 30 \mathrm{Kg} / \mathrm{m}^{2}\right)(\%)^{\mathrm{b}}$ & 45.4 & 53.4 & 48.0 & 38.1 & 48.9 & 46.3 & 43.9 & 40.9 \\
\hline Current smoker & 15.6 & 36.8 & 16.7 & 5.8 & 20.7 & 16.5 & 13.6 & 10.3 \\
\hline $\begin{array}{l}\text { Any macrovascular } \% \\
\text { Coronary } \% \\
\text { Cerebrovascular } \%\end{array}$ & $\begin{array}{l}17.4 \\
11.9 \\
6.7\end{array}$ & $\begin{array}{l}6.4 \\
4.2 \\
1.6\end{array}$ & $\begin{array}{c}16.3 \\
10.5 \\
5.0\end{array}$ & $\begin{array}{l}26.2 \\
15.2 \\
10.8\end{array}$ & $\begin{array}{l}13.1 \\
7.9 \\
4.6\end{array}$ & $\begin{array}{l}17.3 \\
10.6 \\
6.2\end{array}$ & $\begin{array}{l}20.5 \\
12.7 \\
7.2\end{array}$ & $\begin{array}{l}25.0 \\
15.3 \\
9.1\end{array}$ \\
\hline Retinopathy \% & 5.8 & 3.4 & 6.0 & 6.4 & 1.9 & 4.6 & 6.7 & 13.0 \\
\hline Nephropathy \% ${ }^{c}$ & 16.7 & 17.1 & 15.3 & 18.9 & 14.2 & 16.2 & 17.5 & 19.6 \\
\hline $\begin{array}{l}\text { Renal Function }^{\text {d }} \\
\text { eGFR } \geq 60 \mathrm{~mL} / \mathrm{min} / 1.73 \mathrm{~m}^{2}, \% \\
\text { eGFR } 30-59 \mathrm{~mL} / \mathrm{min} / 1.73 \mathrm{~m}^{2}, \% \\
\text { eGFR }<30 \mathrm{~mL} / \mathrm{min} / 1.73 \mathrm{~m}^{2}, \%\end{array}$ & $\begin{array}{c}81.6 \\
17.1 \\
1.3\end{array}$ & $\begin{array}{l}97.4 \\
2.3 \\
0.2\end{array}$ & $\begin{array}{l}87.8 \\
11.4 \\
0.8\end{array}$ & $\begin{array}{c}66.3 \\
31.3 \\
2.4\end{array}$ & $\begin{array}{c}86.9 \\
12.4 \\
0.7\end{array}$ & $\begin{array}{c}82.2 \\
16.6 \\
1.2\end{array}$ & $\begin{array}{c}79.9 \\
18.7 \\
1.4\end{array}$ & $\begin{array}{c}75.6 \\
22.3 \\
2.1\end{array}$ \\
\hline \multicolumn{9}{|l|}{ Glycaemic-lowering step of treatment } \\
\hline $\begin{array}{l}\text { Lifestyle only }(\mathrm{N}=69924)(\%) \\
\mathrm{HbA} 1 \mathrm{c} \text {, mean } \% \\
\mathrm{HbA} 1 \mathrm{c}, \text { mean, } \mathrm{mmol} / \mathrm{mol} \pm \mathrm{SD} \\
\mathrm{HbA} 1 \mathrm{c} \leq 7 \%(\leq 53 \mathrm{mmol} / \mathrm{mol})(\%) \\
\mathrm{BMI} \text {, mean } \mathrm{Kg} / \mathrm{m}^{2} \pm \mathrm{SD}\end{array}$ & $\begin{array}{c}24.4 \\
6.3 \pm 1.0 \\
45.7 \pm 11.0 \\
85.4 \\
29.4 \pm 4.8\end{array}$ & $\begin{array}{c}29.8 \\
6.6 \pm 1.5 \\
49.0 \pm 16.5 \\
75.7 \\
30.5 \pm 5.4\end{array}$ & $\begin{array}{c}23.2 \\
6.3 \pm 0.9 \\
45.5 \pm 10.27 \\
86.1 \\
29.6 \pm 4.7\end{array}$ & $\begin{array}{c}24.1 \\
6.2 \pm 0.8 \\
44.7 \pm 8.9 \\
88.1 \\
28.6 \pm 4.5\end{array}$ & $\begin{array}{c}37.8 \\
6.3 \pm 1.0 \\
45.6 \pm 11.0 \\
86.1 \\
29.8 \pm 4.9\end{array}$ & $\begin{array}{c}25.5 \\
6.3 \pm 1.0 \\
45.7 \pm 11.0 \\
85.2 \\
29.4 \pm 4.7\end{array}$ & $\begin{array}{c}18.5 \\
6.3 \pm 1.0 \\
45.8 \pm 11.0 \\
84.8 \\
28.9 \pm 4.7\end{array}$ & $\begin{aligned} & 12.7 \\
& 6.3 \pm 1.0 \\
& 45.7 \pm 11.0 \\
& 84.4 \\
& 28.3 \pm 4.5\end{aligned}$ \\
\hline $\begin{array}{l}\text { Oral monotherapy (N=101749) (\%) } \\
\mathrm{HbA} 1 \mathrm{c} \text {, mean } \% \\
\mathrm{HbA} 1 \mathrm{c}, \text { mean, } \mathrm{mmol} / \mathrm{mol} \pm \mathrm{SD} \\
\mathrm{HbA} 1 \mathrm{c} \leq 7 \%(\leq 53 \mathrm{mmol} / \mathrm{mol})(\%) \\
\mathrm{BMI} \text {, mean } \mathrm{Kg} / \mathrm{m}^{2} \pm \mathrm{SD}\end{array}$ & $\begin{array}{c}35.5 \\
6.9 \pm 1.3 \\
52.1 \pm 13.9 \\
63.7 \\
29.6 \pm 4.9\end{array}$ & $\begin{array}{c}36.1 \\
7.3 \pm 1.7 \\
56.4 \pm 18.2 \\
54.0 \\
30.9 \pm 5.5\end{array}$ & $\begin{array}{c}35.7 \\
6.9 \pm 1.2 \\
52.1 \pm 13.5 \\
63.3 \\
29.9 \pm 4.9\end{array}$ & $\begin{array}{c}34.9 \\
6.7 \pm 1.1 \\
50.3 \pm 11.9 \\
68.4 \\
28.6 \pm 4.5\end{array}$ & $\begin{array}{c}43.2 \\
6.8 \pm 1.5 \\
51.1 \pm 16.0 \\
68.1 \\
30.2 \pm 5.1\end{array}$ & $\begin{array}{c}37.8 \\
6.9 \pm 1.352 .2 \\
\pm 13.8 \\
63.1 \\
29.7 \pm 4.8\end{array}$ & $\begin{array}{c}32.7 \\
7.0 \pm 1.2 \\
52.8 \pm 13.4 \\
61.1 \\
29.3 \pm 4.8\end{array}$ & $\begin{array}{c}23.5 \\
7.0 \pm 1.2 \\
52.6 \pm 13.0 \\
60.8 \\
28.6 \pm 4.6\end{array}$ \\
\hline $\begin{array}{l}\text { Oral Combined }(\mathrm{N}=64313)(\%) \\
\mathrm{HbA} 1 \mathrm{c} \text {, mean } \% \\
\mathrm{HbA} 1 \mathrm{c}, \text { mean, } \mathrm{mmol} / \mathrm{mol} \pm \mathrm{SD} \\
\mathrm{HbA} 1 \mathrm{c} \leq 7 \%(\leq 53 \mathrm{mmol} / \mathrm{mol})(\%) \\
\text { BMI, mean } \mathrm{Kg} / \mathrm{m}^{2} \pm \mathrm{SD}\end{array}$ & $\begin{array}{c}21.0 \\
7.6 \pm 1.5 \\
59.3 \pm 16.1 \\
40.1 \\
29.6 \pm 5.0\end{array}$ & $\begin{array}{c}19.3 \\
8.1 \pm 1.8 \\
65.2 \pm 19.8 \\
30.9 \\
31.2 \pm 5.8\end{array}$ & $\begin{array}{c}23.9 \\
7.6 \pm 1.4 \\
59.7 \pm 15.6 \\
38.9 \\
30.0 \pm 5.1\end{array}$ & $\begin{array}{c}21.3 \\
7.4 \pm 1.3 \\
56.9 \pm 14.4 \\
45.6 \\
28.4 \pm 4.5\end{array}$ & $\begin{array}{c}11.5 \\
7.6 \pm 1.7 \\
59.3 \pm 18.7 \\
44.3 \\
30.1 \pm 5.4\end{array}$ & $\begin{array}{c}22.0 \\
7.6 \pm 1.5 \\
59.6 \pm 16.3 \\
40.5 \\
29.9 \pm 5.1\end{array}$ & $\begin{array}{c}27.9 \\
7.6 \pm 1.4 \\
59.7 \pm 15.4 \\
38.9 \\
29.6 \pm 5.0\end{array}$ & $\begin{array}{c}29.5 \\
7.5 \pm 1.4 \\
58.9 \pm 14.9 \\
39.5 \\
29.0 \pm 4.8\end{array}$ \\
\hline $\begin{array}{l}\text { Oral }+ \text { Insulin }(\mathrm{N}=29095)(\%) \\
\mathrm{HbA} 1 \mathrm{c} \text {, mean } \% \\
\mathrm{HbA} 1 \mathrm{c}, \text { mean, } \mathrm{mmol} / \mathrm{mol} \pm \mathrm{SD} \\
\mathrm{HbA} 1 \mathrm{c} \leq 7 \%(\leq 53 \mathrm{mmol} / \mathrm{mol})(\%) \\
\text { BMI, mean } \mathrm{Kg} / \mathrm{m}^{2} \pm \mathrm{SD}\end{array}$ & $\begin{array}{c}10.1 \\
8.1 \pm 1.6 \\
65.4 \pm 17.0 \\
24.3 \\
30.6 \pm 5.3\end{array}$ & $\begin{array}{c}7.9 \\
8.7 \pm 1.9 \\
71.1 \pm 20.9 \\
20.7 \\
31.3 \pm 5.9\end{array}$ & $\begin{array}{c}10.8 \\
8.2 \pm 1.5 \\
65.8 \pm 16.7 \\
22.5 \\
31.0 \pm 5.4\end{array}$ & $\begin{array}{c}10.0 \\
7.9 \pm 1.4 \\
62.7 \pm 15.8 \\
28.4 \\
29.5 \pm 4.9\end{array}$ & $\begin{array}{c}3.6 \\
8.0 \pm 1.9 \\
63.7 \pm 20.7 \\
33.9 \\
30.3 \pm 5.5\end{array}$ & $\begin{array}{c}8.2 \\
8.1 \pm 1.6 \\
65.1 \pm 17.4 \\
25.5 \\
30.6 \pm 5.4\end{array}$ & $\begin{array}{c}12.3 \\
8.2 \pm 1.5 \\
65.9 \pm 16.8 \\
23.0 \\
30.7 \pm 5.3\end{array}$ & $\begin{array}{c}20.7 \\
8.1 \pm 1.5 \\
65.1 \pm 16.0 \\
22.5 \\
30.5 \pm 5.3\end{array}$ \\
\hline $\begin{array}{l}\text { Insulin monotherapy }(\mathrm{N}=21710)(\%) \\
\mathrm{HbA} 1 \mathrm{c} \text {, mean } \% \\
\mathrm{HbA} 1 \mathrm{c} \text {, mean, } \mathrm{mmol} / \mathrm{mol} \pm \mathrm{SD} \\
\mathrm{HbA} 1 \mathrm{c} \leq 7 \%(\leq 53 \mathrm{mmol} / \mathrm{mol})(\%) \\
\mathrm{BMI} \text {, mean } \mathrm{Kg} / \mathrm{m}^{2} \pm \mathrm{SD}\end{array}$ & $\begin{array}{c}7.6 \\
7.9 \pm 1.7 \\
62.7 \pm 18.5 \\
32.9 \\
28.6 \pm 5.1\end{array}$ & $\begin{array}{c}6.9 \\
8.6 \pm 2.2 \\
70.9 \pm 24.3 \\
25.1 \\
27.9 \pm 5.6\end{array}$ & $\begin{array}{c}6.4 \\
7.9 \pm 1.7 \\
63.3 \pm 18.6 \\
31.3 \\
29.0 \pm 5.3\end{array}$ & $\begin{array}{c}9.8 \\
7.7 \pm 1.5 \\
60.2 \pm 16.2 \\
36.2 \\
28.6 \pm 4.9\end{array}$ & $\begin{array}{c}3.9 \\
7.7 \pm 2.0 \\
60.7 \pm 22.2 \\
44.9 \\
29.2 \pm 5.1\end{array}$ & $\begin{array}{c}6.5 \\
7.9 \pm 1.7 \\
62.4 \pm 18.6 \\
33.8 \\
28.8 \pm 5.3\end{array}$ & $\begin{array}{c}8.6 \\
7.9 \pm 1.6 \\
62.9 \pm 17.9 \\
31.7 \\
28.6 \pm 5.1\end{array}$ & $\begin{array}{c}13.7 \\
8.0 \pm 1.6 \\
63.6 \pm 17.5 \\
28.8 \\
28.9 \pm 5.0\end{array}$ \\
\hline
\end{tabular}

${ }^{a} \mathrm{~N}=214,867$ patients with $\mathrm{HbA} 1 \mathrm{c}$ available. ${ }^{\mathrm{b}} 202,451$ with body mass index (BMI) available ${ }^{\mathrm{c}}$ Micro- or Macroalbuminuria ${ }^{\mathrm{d}} \mathrm{N}=202,938$ with plasma creatinine available for calculating estimated glomerular filtration rate (eGFR)

Table 1: Patient characteristics, according to age groups, steps of treatment and diabetes duration.

\section{Pharmacological treatment in patients with chronic renal impairment}

Steps of treatment according to renal function are shown in Table 2. Mild renal impairment increased from $15 \%$ in patients treated only with lifestyle modifications to $29.4 \%$ in patients treated with insulin. Severe renal impairment was more frequent in patients treated with insulin monotherapy $(6.8 \%)$ than other steps of treatment (from $0.6 \%$ to $1.5 \%)$. Data about drugs used in patients with chronic renal impairment are shown in Table 3. It is to be noted that some of these individuals were treated with drugs completely contraindicated in patients with eGFR $<30 \mathrm{ml} / \mathrm{min}$. A remarkable proportion $(12.1 \%)$ of patients with severe renal impairment were taking sulfonylureas, mainly glicazide $(41 \%)$, glibenclamide $(33 \%)$ and glimepiride $(17 \%)$, and $366(16.2 \%)$ on metformin. On the other hand, $42.6 \%$ of those patients were treated with insulin (alone or in combination).

\section{Glycaemic control according to patient characteristics}

Good glycaemic control (HbA1c $\leq 7 \%, \leq 53 \mathrm{mmol} / \mathrm{mol}$ ) was associated mostly with older age groups $(49.3 \%$ among patients younger than 55 years and $60 \%$ of those $\geq 75$ years old). By contrast, the significance of the gender variable has no clinical relevance $(57 \%$ of women vs. $56 \%$ of men). Likewise, better glycaemic control was associated with patients who were not obese, did not smoke, and were receiving dietary treatment. Thus, the prevalence of patients with good glycaemic control ranges from $24 \%$ of those treated with insulin in combination with oral agents up to $85 \%$ of patients with 


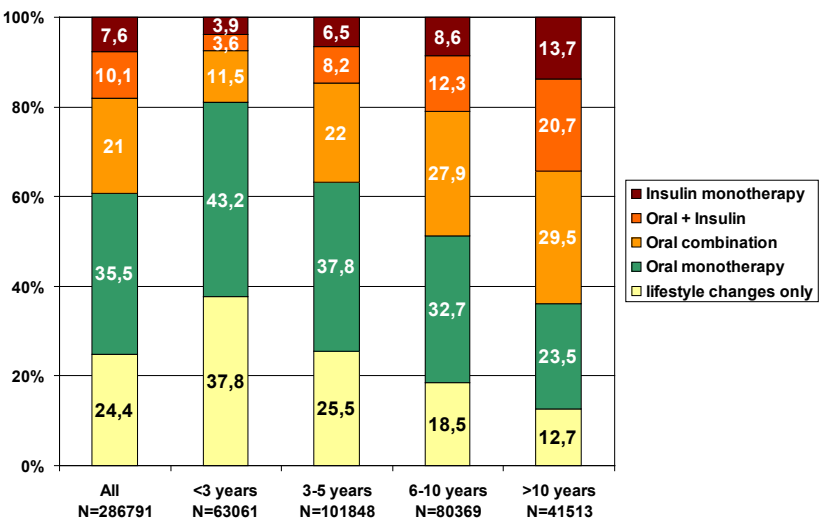

Figure 1: Glycaemic-lowering step of treatment according to intervals of diabetes duration

dietary treatment (Table 2): the greater the diabetes duration and/ or complexity of treatment, the fewer patients with good glycaemic control. Patients with severe renal impairment (eGFR $<30 \mathrm{ml} / \mathrm{min}$ ) also had better glycaemic control than those with eGFR $\geq 60 \mathrm{ml} / \mathrm{min}$ ( $62 \%$ vs $56 \%$, respectively). On the other hand, figures on very poor control, defined as $\mathrm{HbAlc}>10 \%(>86 \mathrm{mmol} / \mathrm{mol}),(5 \%$ of the total population), increased with the duration of diabetes: $4.2 \%$ of subjects with $\leq 2$ years duration and $5.8 \%$ in those with $>10$ years. The presence of microvascular complications also increased these figures, from $4.2 \%$ in patients with none to $9.1 \%$ among those with 2 complications. Regarding treatment, the group of subjects receiving insulin alone or combined with oral agents had the worst control $(10.2 \%$ and $11.2 \%$ with $\mathrm{HbAlc}>10 \%$ ( $>86 \mathrm{mmol} / \mathrm{mol}$ ), respectively) while in patients treated with lifestyle changes, oral monotherapy or combined oral agents, figures were notably better $(1.4 \%, 3.1 \%$ and $6.7 \%$, respectively).

\section{Multivariable analysis of good glycaemic control}

After adjusting the multivariable analysis for age, sex, BMI, hypertension, low-density lipoprotein cholesterol control, macrovascular disease, heart failure, renal function, presence of nephropathy and current smoking habit (Table 4), increased diabetes duration and antihyperglycaemic step of treatment were the most relevant variables related to good glycaemic control. Patients with the lowest adjusted Odds Ratios (aOR) were those treated with insulin plus oral agents compared to metformin in model 1 (glycaemic lowering agents) and to lifestyle changes in model 2 (steps of treatment) (aOR 0.33 and 0.05 respectively), and those with longer diabetes duration (aOR 0.44 in model 1 and 0.58 in model 2). In comparison with patients on metformin as a reference (model 1), lifestyle changes were positively related to good glycaemic control (aOR 4.48) while the rest of pharmacological treatments, especially insulin, were negatively related (aOR between 0.86 and 0.33 ).

In relation to glycaemic control by age groups, an aOR of 1.89 was observed between patients older than 75 years and those younger than 55 years. Finally, an aOR of 2.17 was observed in patients with severe renal impairment (eGFR $<30 \mathrm{ml} / \mathrm{min}$ ) vs. patients with eGFR $>60 \mathrm{ml} /$ $\min$.

\section{Discussion}

This population-based study shows that glycaemic control deteriorates with the duration of the disease and the more complex steps of treatment, particularly among insulin-treated patients. The major strength of our study is the inclusion of every patient with T2DM from a total population database of $3,755,038$ persons over age 30 , providing data from 286,791 diabetic patients. Moreover, $96 \%$ of the patients with T2DM had contacted the healthcare system during the year of study at least once. With regard to methodology, the accuracy of the results is strengthened by the existing link between primary care clinical records and prescriptions obtained from the pharmacy database. The diabetes literature about the treatment of T2DM is enormous, and a lot of database studies have been done in North and central Europe and in North America [16-28], but this is the first one that provides data from a Mediterranean area. Further, this study is based on the whole population.

The degree of glycaemic control observed is similar to previously published studies [10-19]. The recommended $\mathrm{HbA}_{1 \mathrm{c}} \leq 7 \%(\leq 53 \mathrm{mmol} /$ mol) goal was reached by two thirds of the total population, but less than one-third of the insulin-treated patients with 6 or more years of diabetes duration. The percentage of patients on pharmacological treatment $(75.6 \%)$ was high, taking into account that only patients who were receiving continuous treatment with glucose-lowering drugs were considered. Most patients receiving medication were managed with oral glucose-lowering treatment $(56.5 \%)$, while $17.7 \%$ were treated with insulin, either alone or combined with oral agents. The percentage of non-medicated patients was similar to other studies carried out in Spain, but lower than reported in a recent study in Sweden $(33.4 \%)$ [19]. It is to be noted that the percentage of patients who reached the objective of $\mathrm{HbAlc} \leq 7 \%(\leq 53 \mathrm{mmol} / \mathrm{mol})$ decreased dramatically with the progression of treatment ( $85.4 \%$ for lifestyle only to $24.3 \%$ for insulin combined with oral agents). These results are generally similar to the figures observed in a recently published study, with a similar methodology, by Ekström et al. in 163,121 T2DM patients from a Swedish population register for 2009 [19]. The degree of control by steps of treatment was very similar: $84.8 \%$ of patients treated with lifestyle changes reached the objective (HbAlc $\leq 7 \%, \leq 53 \mathrm{mmol} /$ $\mathrm{mol}$ ), whereas this percentage was notably lower in patients treated with insulin in combination with oral agents (25\%) [19]. Mean HbA1c values were also similar to that of our study, steadily increasing from $6.4 \%(46 \mathrm{mmol} / \mathrm{mol})$ in patients treated only with lifestyle changes, $6.8 \%(51 \mathrm{mmol} / \mathrm{mol})$ with oral monotherapy, $7.1 \%(54 \mathrm{mmol} / \mathrm{mol})$ with two oral drugs and $7.4 \%(57 \mathrm{mmol} / \mathrm{mol})$ to $7.9 \%(63 \mathrm{mmol} / \mathrm{mol})$ with different patterns of insulin therapy (alone or in combination with oral drugs) [19].

We interpret these findings as a consequence of clinicians not prescribing drug treatment to well-controlled patients, while prescribing metformin to moderately well controlled patients and combined oral agents or insulin-based treatment to less-controlled patients. On the other hand, this disappointing result is probably related to the fact that therapeutic changes are sometimes introduced after several years of uncontrolled HbAlc, frequently above $8 \%$ (64 $\mathrm{mmol} / \mathrm{mol})$, or even $9 \%(75 \mathrm{mmol} / \mathrm{mol})$ [29-33]. In some cases there is a delay in the intensification of treatment, or so-called therapeutic inertia that has been described to happen in $30 \%$ to $60 \%$ of patients with insufficient control [34]. In a recent study in a primary care centre in Catalonia, therapeutic inertia was observed in $40.6 \%$ of patients with $\mathrm{HbAlc}>7 \%(>53 \mathrm{mmol} / \mathrm{mol})$ [35]. Moreover, a multicentre Spanish study reported a prescription change from oral monotherapy to bitherapy when $\mathrm{HbAlc}$ reached a mean of $8.1 \%(65 \mathrm{mmol} / \mathrm{mol})$ in patients whose values had exceeded $7 \%(53 \mathrm{mmol} / \mathrm{mol})$ for a mean period of 2 years [36]. Guidelines propose an early introduction and 
Page 5 of 7

\begin{tabular}{|c|c|c|c|c|c|c|}
\hline & $\begin{array}{l}\text { All patients } \\
(\mathrm{N}=286791)\end{array}$ & $\begin{array}{l}\text { Lifestyle changes } \\
\qquad(N=69924)\end{array}$ & $\begin{array}{l}\text { Oral monotherapy } \\
\quad(\mathrm{N}=101749)\end{array}$ & $\begin{array}{l}\text { Oral combined } \\
(\mathrm{N}=64313)\end{array}$ & $\begin{array}{c}\text { Oral } \\
+ \text { Insulin } \\
(\mathrm{N}=29095)\end{array}$ & $\begin{array}{c}\text { Insulin } \\
\text { monotherapy } \\
(\mathrm{N}=\mathbf{2 1 7 1 0})\end{array}$ \\
\hline Age ( years) mean (SD) & $68.2(11.4)$ & $67.5(12.2)$ & $68.1(11.4)$ & $68.2(10.6)$ & $68.7(10.4)$ & $70.2(11.9)$ \\
\hline Sex, (\% of males) & 53.7 & 54.2 & 55.0 & 54.8 & 46.6 & 52.3 \\
\hline Diabetes duration, mean years (SD) & $6.5(5.1)$ & $5.03(3.97)$ & $5.63(4.14)$ & $7.58(4.99)$ & $9.30(6.47)$ & $8.86(6.86)$ \\
\hline $\mathrm{HbA}_{1 \mathrm{c}}, \%$ mean $(\mathrm{SD})^{\mathrm{a}}$ & $7.1(1.5)$ & $6.3(1.0)$ & $6.9(1.3)$ & $7.6(1.5)$ & $8.1(1.6)$ & $7.9(1.7)$ \\
\hline $\mathrm{HbA}_{1 \mathrm{c}}, \mathrm{mmol} / \mathrm{mol}$, mean (SD) ${ }^{\mathrm{a}}$ & $54.6 \pm 16.0$ & $45.7 \pm 11.0$ & $52.1 \pm 14.0$ & $59.4 \pm 16.1$ & $65.4 \pm 17.0$ & $62.7 \pm 18.5$ \\
\hline $\mathrm{HbA}_{1 \mathrm{c}} \leq 7 \%(\leq 53 \mathrm{mmol} / \mathrm{mol})(\%)^{\mathrm{a}}$ & 56.1 & 85.4 & 63.7 & 40.1 & 24.3 & 32.9 \\
\hline $\mathrm{BMI}\left(\mathrm{Kg} / \mathrm{m}^{2}\right)$, mean $(\mathrm{SD})^{\mathrm{b}}$ & $29.6(5.0)$ & $29.4(4.8)$ & $29.6(4.9)$ & $29.6(5.0)$ & $30.6(5.3)$ & $28.7(5.1)$ \\
\hline Obesity $\left(\mathrm{BMI} \geq 30 \mathrm{~kg} / \mathrm{m}^{2}\right)(\%)^{\mathrm{b}}$ & 45.4 & 43.8 & 45.5 & 45.2 & 53.4 & 38.3 \\
\hline Current Smoker & 15.6 & 16.8 & 16.3 & 15.0 & 12.6 & 15.2 \\
\hline Any Macrovascular & 17.4 & 13.5 & 16.7 & 18.2 & 27.1 & 30.9 \\
\hline Coronary \% & 11.9 & 8,1 & 10.2 & 11.1 & 17.1 & 19.0 \\
\hline Cerebrovascular \% & 6.7 & 5.0 & 6.1 & 6.0 & 9.3 & 11.5 \\
\hline Retinopathy \% & 5.8 & 1.5 & 2.7 & 6.3 & 17.8 & 17.0 \\
\hline Nephropathyc\% & 16.7 & 11.3 & 14.3 & 17.7 & 25.2 & 28.6 \\
\hline $\begin{array}{l}\text { Renal function }{ }^{d} \% \\
\text { eGFR } \geq 60 \mathrm{~mL} / \mathrm{min} / 1.73 \mathrm{~m}^{2}, \% \\
\text { eGFR } 30-59 \mathrm{~mL} / \mathrm{min} / 1.73 \mathrm{~m}^{2}, \% \\
\text { eGFR }<30 \mathrm{~mL} / \mathrm{min} / 1.73 \mathrm{~m}^{2}, \%\end{array}$ & $\begin{array}{c}81.6 \\
17.1 \\
1.3\end{array}$ & $\begin{array}{c}83.7 \\
15.2 \\
1.1\end{array}$ & $\begin{array}{c}83.9 \\
15.4 \\
0.7\end{array}$ & $\begin{array}{c}83.4 \\
16.0 \\
0.6\end{array}$ & $\begin{array}{c}76.7 \\
21.7 \\
1.5\end{array}$ & $\begin{array}{c}63.7 \\
29.4 \\
6.8\end{array}$ \\
\hline
\end{tabular}

${ }^{a} \mathrm{~N}=214,867$ patients with at least one $\mathrm{HbA} 1 \mathrm{c}$ measurement. ${ }^{\mathrm{b}} 202,451$ with body mass index (BMI) available ${ }^{\mathrm{c}}$ Microalbuminuria or macroalbuminuria,

${ }^{d} \mathrm{~N}=202,938$ with plasma creatinine available for calculating estimated glomerular filtration rate (eGFR)

Table 2: Patient characteristics according to glycaemic-lowering step of treatment.

\begin{tabular}{|c|c|c|c|c|c|c|c|c|c|c|c|c|c|}
\hline & $\begin{array}{c}\text { Total } \\
\mathbf{N}=286791\end{array}$ & $\begin{array}{c}\text { Men } \\
\mathrm{N}=153987\end{array}$ & $\begin{array}{c}\text { Women } \\
\mathrm{N}=132804\end{array}$ & $\begin{array}{c}<55 \\
\text { years } \\
\mathrm{N}=37221\end{array}$ & $\begin{array}{c}55-74 \\
\text { years } \\
\mathrm{N}=153250\end{array}$ & $\begin{array}{c}\geq 75 \\
\text { years } \\
\mathrm{N}=96320\end{array}$ & $\begin{array}{l}<=2 \text { years } \\
\text { duration } \\
N=46923\end{array}$ & $\begin{array}{l}3-5 \text { years } \\
\text { duration } \\
N=74383\end{array}$ & $\begin{array}{c}\text { 6-10 years } \\
\text { duration } \\
N=61052\end{array}$ & $\begin{array}{l}>10 \text { years } \\
\text { duration } \\
\mathrm{N}=32509\end{array}$ & $\begin{array}{c}\text { eGFR } \\
\geq 60 \\
\mathrm{~N}=157305\end{array}$ & \begin{tabular}{|c|} 
eGFR \\
$30-59$ \\
$\mathrm{~N}=32597$
\end{tabular} & $\begin{array}{c}\text { eGFR } \\
<30 \\
N=2266\end{array}$ \\
\hline Lifestyle Only & 24.4 & 24.6 & 24.1 & 29.8 & 23.2 & 24.1 & 37.8 & 25.5 & 18.5 & 12.7 & 22.0 & 19.0 & 19.0 \\
\hline Metformin & 41.2 & 41.7 & 40.5 & 44.7 & 44.3 & 34.9 & 43.8 & 41.8 & 40.6 & 36.6 & 45.8 & 36.4 & 16.2 \\
\hline Sulphonylurea & 17.4 & 17.7 & 17.2 & 11.4 & 16.6 & 21.2 & 10.0 & 17.6 & 21.1 & 21.2 & 17.9 & 19.9 & 12.1 \\
\hline Glitazone & 0.8 & 0.8 & 0.9 & 0.8 & 0.9 & 0.8 & 0.3 & 0.8 & 1.1 & 1.2 & 0.7 & 1.1 & 1.2 \\
\hline Glinide & 2.4 & 2.4 & 2.4 & 1.7 & 2.3 & 2.9 & 1.5 & 2.5 & 2.8 & 2.8 & 2.1 & 3.6 & 8.0 \\
\hline Insulin & 12.4 & 11.5 & 13.5 & 10.7 & 11.5 & 14.5 & 5.6 & 10.4 & 14.3 & 23.9 & 10.0 & 18.3 & 42.6 \\
\hline Other ${ }^{a}$ & 1.4 & 1.3 & 1.4 & 1.0 & 1.3 & 1.6 & 1.0 & 1.4 & 1.5 & 1.5 & 1.3 & 1.6 & 0.9 \\
\hline
\end{tabular}

aOther: Alphaglucosidase inhibitor, DPP4 inhibitor or GLP-1 analog (exenatide) eGFR: Estimated Glomerular Filtration Rate

Table 3: Use of glycaemic-lowering drugs by age, sex, diabetes duration and renal function.

progression in the combination of drugs [6-9] to prevent the worsening of glycaemic control when more complex therapies are delayed, but the benefit of this strategy has not been demonstrated.

The prevalence of impaired renal function in our study $(18.4 \%)$ is inferior to that observed in two British studies, 25.5\% [31] and $27.8 \%$ [32], and in one large database in the USA, 35.2\% [30]. The National Institute for Health and Clinical Excellence (NICE) [9] and the Spanish local guidelines $[6,7]$ propose that metformin should not be prescribed when severe renal impairment is established (eGFR $<30 \mathrm{ml} / \mathrm{min}$ ). It seems very reasonable considering the large number of older people who could be deprived of the benefits of metformin treatment. On the other hand, professionals should instruct the patient to immediately suspend metformin in any acute situation that predisposes to lactic acidosis (diarrhoea, infections with high fever, etc.). The surprisingly high percentage of patients with severe renal impairment taking metformin (16.2\%) observed in our study was similar to an American study in which $19.6 \%$ of patients with severe impaired renal function (1,673 of 8,522 patients) were taking this drug [32]. This puts a high number of patients at high risk of medication-related severe adverse events. Our institution recently implemented a new aid for prescription, integrated with the electronic medical record system, that automatically alerts physicians of this contraindication.

A potential limitation of this study is the incomplete data for some of the studied variables. However, this is the first broad populationbased study in Spain, the present results are comparable to previous publications by other authors, and the validity of the use of the SIDIAP database has been recently assessed by other studies [37-39]. Another limitation of the study, due to its retrospective design, is the lack of information about the exact timing of the HbAlc measurement in relation to possible changes in the steps of treatment: some values might have been measured just before the change and others later on. This problem is common to almost all cross-sectional studies. Finally, the fact that we analysed the medication taken from the pharmacist does not allow us to assume that all patients took their medications as prescribed.

In conclusion, in this study, patients of advanced age and those treated with only lifestyle changes show the best degree of control. Glycaemic control deteriorates with the progression of the disease 
Citation: Mata-Cases M, Mauricio D, Vinagre I, Morros R, Hermosilla E, et al. (2014) Treatment of Hyperglycaemia in Type 2 Diabetic Patients in a Primary Care Population Database in a Mediterranean Area (Catalonia, Spain). J Diabetes Metab 5: 338. doi:10.4172/2155-6156.1000338

Page 6 of 7

\begin{tabular}{|c|c|c|c|c|c|c|}
\hline & ORc & $95 \% \mathrm{Cl}$ & $p$ value & ORa & $95 \% \mathrm{Cl}$ & $p$ value \\
\hline Age $55-74$ (vs $<55$ years-old) & 1.27 & $1.23-1.30$ & $<0.001$ & 1.47 & $1.43-1.52$ & $<0.001$ \\
\hline Age $\geq 75$ (vs $<55$ years-old) & 1.53 & $1.48-1.57$ & $<0.001$ & 1.89 & $1.83-1.96$ & $<0.001$ \\
\hline Male Sex (vs female) & 0.97 & $0.95-0.98$ & $<0.001$ & 0.99 & $0.97-1.01$ & 0.340 \\
\hline Obesity (BMI $\geq 30 \mathrm{~kg} / \mathrm{m}^{2}$ ) & 0.87 & $0.87-0.91$ & $<0.001$ & 0.84 & $0.83-0.86$ & $<0.001$ \\
\hline Hypertension & 1.16 & $1.14-1.80$ & $<0.001$ & 1.19 & $1.17-1.22$ & $<0.001$ \\
\hline Current Smoker & 0.83 & $0.81-0.85$ & $<0.001$ & 0.91 & $0.88-0.94$ & $<0.001$ \\
\hline Diabetes Duration 3-5 years (vs $\leq 2$ years) & 0.59 & $0.58-0.61$ & $<0.001$ & 0.66 & $0.64-0.68$ & $<0.001$ \\
\hline Diabetes Duration $6-10$ years (vs $\leq 2$ years) & 0.45 & $0.43-0.46$ & $<0.001$ & 0.53 & $0.52-0.55$ & $<0.001$ \\
\hline Diabetes Duration $>10$ years (vs $\leq 2$ years) & 0.33 & $0.32-0.34$ & $<0.001$ & 0.44 & $0.42-0.45$ & $<0.001$ \\
\hline LDL-Cholesterol control & 1.02 & 0.99-1.03 & 0.120 & 1.30 & $1.27-1.32$ & $<0.001$ \\
\hline Any macrovascular complication & 0.94 & $0.92-0.96$ & $<0.001$ & 1.11 & $1.08-1.14$ & $<0.001$ \\
\hline Heart Failure & 0.99 & $0.96-1.04$ & 0.898 & 1.07 & $1.02-1.13$ & 0.003 \\
\hline $\begin{array}{l}\text { Nephropathy } \\
\text { Microalbuminuria } \\
\text { Macroalbuminuria }\end{array}$ & $\begin{array}{l}0.63 \\
0.56\end{array}$ & $\begin{array}{l}0.62-0.65 \\
0.52-0.61\end{array}$ & $\begin{array}{l}<0.001 \\
<0.001\end{array}$ & $\begin{array}{l}0.71 \\
0.66\end{array}$ & $\begin{array}{l}0.69-0.74 \\
0.61-0.72\end{array}$ & $\begin{array}{l}<0.001 \\
<0.001\end{array}$ \\
\hline eGFR $30-59$ (vs $\geq 60$ ) & 1.11 & 1.08-1.14 & $<0.001$ & 1.21 & $1.18-1.25$ & $<0.001$ \\
\hline eGFR <30 (vs $\geq 60$ ) & 1.29 & $1.19-1.41$ & $<0.001$ & 2.17 & $1.97-2.39$ & $<0.001$ \\
\hline \multicolumn{7}{|l|}{ Model 1: Glycaemic-lowering treatments (vs. Metformin) } \\
\hline Lifestyle Only & 4.80 & $4.66-4.95$ & $<0.001$ & 4.48 & 4.35-4.62 & $<0.001$ \\
\hline Sulfonylureas & 0.66 & 0.64-0.67 & $<0.001$ & 0.66 & $0.64-0.67$ & $<0.001$ \\
\hline Glitazones & 0.80 & $0.73-0.88$ & $<0.001$ & 0.87 & $0.79-0.95$ & $<0.001$ \\
\hline Glinides & 0.58 & $0.55-0.61$ & $<0.001$ & 0.55 & $0.52-0.59$ & $<0.001$ \\
\hline Insulin & 0.33 & $0.32-0.34$ & $<0.001$ & 0.33 & $0.32-0.34$ & $<0.001$ \\
\hline Other (AlphaGlucosidase inhibitors, DPP4 Inhibitors, Exenatide) & 0.86 & $0.80-0.93$ & $<0.001$ & 0.86 & $0.80-0.93$ & $<0.001$ \\
\hline \multicolumn{7}{|c|}{ Model 2: Glycaemic-lowering steps of treatment (vs. lifestyle changes only) } \\
\hline Oral antidiabetic monotherapy & 0.29 & $0.29-0.30$ & $<0.001$ & 0.30 & $0.29-0.30$ & $<0.001$ \\
\hline Combined oral antidiabetics & 0.11 & $0.11-0.11$ & $<0.001$ & 0.12 & $0.11-0.12$ & $<0.001$ \\
\hline Oral antidiabetic drug + Insulin & 0.05 & $0.05-0.06$ & $<0.001$ & 0.05 & $0.05-0.06$ & $<0.001$ \\
\hline Insulin monotherapy & 0.08 & $0.08-0.08$ & $<0.001$ & 0.08 & $0.75-0.82$ & $<0.001$ \\
\hline
\end{tabular}

cOR: Crude Odds Ratio; aOR Adjusted Odds Ratio; C195\%: Confidence Interval 95\%; eGFR (MDRD): Estimated Glomerular Filtration Rate

* Adjusted for: age, sex, BMI, hypertension, LDL-cholesterol control ( $<100 \mathrm{mg} / \mathrm{dl}$ in secondary prevention; $<130 \mathrm{mg} / \mathrm{dl}$ in primary prevention), macrovascular disease, heart failure, renal function, presence of nephropathy and current smoking habit

Table 4: Multivariate analysis: Variables associated with good glycaemic control $(\mathrm{HbA} 1 \mathrm{c} \leq 7 \% ; \leq 53 \mathrm{mmol} / \mathrm{mol})^{*}$.

despite the treatment intensification. Moreover, there is still a gap between the mean $\mathrm{HbA}_{1 \mathrm{c}}$ levels observed and the recommended targets, probably reflecting the insufficient effects of the currently available therapeutic options. Impaired renal function was frequent and some of these patients were taking contraindicated drugs, a situation that must be corrected. The upcoming follow-up of this cohort offers a unique opportunity to show the effectiveness and durability of the different types of treatment and, more interestingly, differences in the incidence of cardiovascular disease, cancer or even mortality.

\section{Take Home Messages}

- As diabetes progresses, glycaemic control deteriorates despite the treatment intensification, particularly among insulintreated patients.

- Lower steps of treatment, advanced age and fewer years of diabetes duration were positively related to good glycaemic control.

- Impaired renal function was frequent and a remarkable proportion of these patients were taking contraindicated drugs.

\section{Funding}

The Catalan Diabetes Association, the Catalan Health Department and part of an unrestricted grant provided by Sanofi-Aventis Spain supported this study, as well as the Network of Preventive Activities and Health Promotion in Primary Care (redlAPP) granted by the Instituto de Salud Carlos III (RD06/0018).

\section{References}

1. Whiting DR, Guariguata L, Weil C, Shaw J (2011) IDF diabetes atlas: global estimates of the prevalence of diabetes for 2011 and 2030. Diabetes Res Clin Pract 94: 311-321.

2. Li R, Zhang P, Barker LE, Chowdhury FM, Zhang X (2010) Cost-effectiveness of interventions to prevent and control diabetes mellitus: a systematic review. Diabetes Care 33: 1872-1894.

3. IDF Clinical Guidelines Task Force (2006) Global Guideline for Type 2 Diabetes: recommendations for standard, comprehensive, and minimal care. Diabet Med 23: 579-593.

4. Ministerio de Sanidad y Consumo (2008). Guia de práctica clínica sobre diabetes tipo 2. Available at: http://www.guiasalud.es/viewGPC.asp?idGuia=429

5. Menéndez Torre E, Lafita Tejedor J, Artola Menéndez S, Millán Núñez-Cortés J, Alonso García A, et al. Sociedad Española de Diabetes (2010) Documento de consenso. Recomendaciones para el tratamiento farmacológico de la hiperglucemia en la diabetes tipo 2. Av Diabetol 26: 331-338.

6. Cano JF, Franch J Mata M, Grupo de Estudio de la Diabetes en Atención Primaria de Salud (GEDAPS) (2004) Guía para el tratamiento de la diabetes tipo 2 en Atención Primaria. Madrid, Harcourt Ed.

7. Mata-Cases M, Cos-Claramunt FX, Morros R, Diego L, Barrot J, et al. (2009) Abordatge de la diabetes mellitus tipus 2 [article online].

8. American Diabetes Association (2012) Standards of medical care in diabetes--2012. Diabetes Care 35: S11-63.

9. NICE (National Institute for Health and Clinical Excellence) (2011) Clinical guideline CG87. Type 2 diabetes: the management of type 2 diabetes.

10. Liebl A, Mata M, Eschwège E; CODE-2 Advisory Board (2002) Evaluation of risk factors for development of complications in Type II diabetes in Europe. Diabetologia 45: S23-28. 
Citation: Mata-Cases M, Mauricio D, Vinagre I, Morros R, Hermosilla E, et al. (2014) Treatment of Hyperglycaemia in Type 2 Diabetic Patients in a Primary Care Population Database in a Mediterranean Area (Catalonia, Spain). J Diabetes Metab 5: 338. doi:10.4172/2155-6156.1000338

Page 7 of 7

11. Benito López P, García Mayor R, Puig Domingo M, Mesa Manteca J, Pallardo Sánchez LF, et al. (2004) [Pathological characteristics of patients with diabetes mellitus type 2, in Spanish Primary Care]. Rev Clin Esp 204: 18-24.

12. Orozco-Beltrán D, Gil-Guillen VF, Quirce F, Navarro-Perez J, Pineda M, et al. (2007) Control of diabetes and cardiovascular risk factors in patients with type 2 diabetes in primary care. The gap between guidelines and reality in Spain. Int $\mathrm{J}$ Clin Pract 61: 909-915.

13. Franch Nadal J, Artola Menéndez S, Diez Espino J, Mata Cases M; en representación de la Red de Grupos de Estudio de la Diabetes en Atención Primaria de la Salud (2010) [The evolution of quality care indicators of patients with type 2 diabetes in the Spanish primary care (1996-2007). The RedGEDAPS quality of care program]. Med Clin (Barc) 135: 600-607.

14. Mata-Cases $M$, Roura-Olmeda $P$, Berengué-Iglesias $M$, Birulés-Pons $M$ Mundet-Tuduri $X$, et al. (2012) Fifteen years of continuous improvement of quality care of type 2 diabetes mellitus in primary care in Catalonia, Spain. Int J Clin Pract 66: 289-298.

15. Vinagre I, Mata-Cases M, Hermosilla E, Morros R, Fina F, et al. (2012) Control of glycemia and cardiovascular risk factors in patients with type 2 diabetes in primary care in Catalonia (Spain). Diabetes Care 35: 774-779.

16. Eliasson B, Cederholm J, Nilsson P, Gudbjörnsdóttir S; Steering Committee of the Swedish National Diabetes Register (2005) The gap between guidelines and reality: Type 2 diabetes in a National Diabetes Register 1996-2003. Diabe Med 22: 1420-1426.

17. Eliasson B, Eeg-Olofsson K, Cederholm J, Nilsson PM, Gudbjörnsdóttir S Steering Committee of the Swedish National Diabetes Register (NDR) (2007) Antihyperglycaemic treatment of type 2 diabetes: results from a national diabetes register. Diabetes Metab 33: 269-276.

18. Carstensen B, Borch-Johnsen K (2011) Register-based studies of diabetes Scand J Public Health 39: 175-179.

19. Ekström N, Miftaraj M, Svensson AM, Andersson Sundell K, Cederholm J, et al (2012) Glucose-lowering treatment and clinical results in 163121 patients with type 2 diabetes: an observational study from the Swedish national diabetes register. Diabetes Obes Metab 14: 717-726.

20. Evans JM, Ogston SA, Emslie-Smith A, Morris AD (2006) Risk of mortality and adverse cardiovascular outcomes in type 2 diabetes: a comparison of patients treated with sulfonylureas and Metformin. Diabetologia 49: 930-936.

21. Johnson JA, Simpson SH, Toth EL, Majumdar SR (2005) Reduced cardiovascular morbidity and mortality associated with metformin use in subjects with Type 2 diabetes. Diabet Med 22: 497-502.

22. Simpson SH, Majumdar SR, Tsuyuki RT, Eurich DT, Johnson JA (2006) Doseresponse relation between sulfonylurea drugs and mortality in type 2 diabetes mellitus: a population-based cohort study. CMAJ 174: 169-174.

23. Tzoulaki I, Molokhia M, Curcin V, Little MP, Millett CJ, et al. (2009) Risk of cardiovascular disease and all cause mortality among patients with type 2 diabetes prescribed oral antidiabetes drugs: retrospective cohort study using UK general practice research database. BMJ 339: b4731.

24. Schramm TK, Gislason GH, Vaag A, Rasmussen JN, Folke F, et al. (2011) Mortality and cardiovascular risk associated with different insulin secretagogues compared with metformin in type 2 diabetes, with or without a previous myocardial infarction: a nationwide study. Eur Heart J 32: 1900-1908.

25. Andersson C, Olesen JB, Hansen PR, Weeke P, Norgaard ML, et al. (2010) Metformin treatment is associated with a low risk of mortality in diabetic patients with heart failure: a retrospective nationwide cohort study. Diabetologia 53:
2546-2553.

26. Gamble JM, Simpson SH, Eurich DT, Majumdar SR, Johnson JA (2010) Insulin use and increased risk of mortality in type 2 diabetes: a cohort study. Diabetes Obes Metab 12: 47-53.

27. Evans JM, Doney AS, AIZadjali MA, Ogston SA, Petrie JR, et al. (2010) Effect of Metformin on mortality in patients with heart failure and type 2 diabetes mellitus. Am J Cardiol 106: 1006-1010.

28. van Staa TP, Patel D, Gallagher AM, de Bruin ML (2012) Glucose-lowering agents and the patterns of risk for cancer: a study with the General Practice Research Database and secondary care data. Diabetologia 55: 654-665.

29. Bolíbar B, Fina Avilés F, Morros R, Garcia-Gil Mdel M, Hermosilla E, et al (2012) [SIDIAP database: electronic clinical records in primary care as a source of information for epidemiologic research]. Med Clin (Barc) 138: 617-621.

30. Meyers JL, Candrilli SD, Kovacs B (2011) Type 2 diabetes mellitus and renal impairment in a large outpatient electronic medical records database: rates of diagnosis and antihyperglycemic medication dose adjustment. Postgrad Med 123: $133-143$.

31. Warren RE, Strachan MW, Wild S, McKnight JA (2007) Introducing estimated glomerular filtration rate (eGFR) into clinical practice in the UK: implications for the use of metformin. Diabet Med 24: 494-497.

32. Shaw JS, Wilmot RL, Kilpatrick ES (2007) Establishing pragmatic estimated GFR thresholds to guide metformin prescribing. Diabet Med 24: 1160-1163.

33. Brown JB, Nichols GA, Perry A (2004) The burden of treatment failure in type 2 diabetes. Diabetes Care 27: 1535-1540

34. Phillips LS, Twombly JG (2008) It's time to overcome clinical inertia. Ann Intern Med 148: 783-785.

35. López-Simarro F, Brotons C, Moral I, Cols-Sagarra C, Selva A, et al. (2012) [Inertia and treatment compliance in patients with type 2 diabetes in primary care]. Med Clin (Barc) 138: 377-384.

36. Conthe P, Mata M, Orozco D, Pajuelo F, Barreto CS, et al. (2011) Degree of control and delayed intensification of antihyperglycaemic treatment in type 2 diabetes mellitus patients in primary care in Spain. Diabetes Res Clin Pract 91: 108-114.

37. Ramos R, Balló E, Marrugat J, Elosua R, Sala J, et al. (2012) Validity for use in research on vascular diseases of the SIDIAP (Information System for the Development of Research in Primary Care): the EMMA study. Rev Esp Cardiol (Engl Ed) 65: 29-37.

38. Pagès-Castellà $A$, Carbonell-Abella $C$, Avilés FF, Alzamora $M$, Baena-Díez $\mathrm{JM}$, et al. (2012) "Burden of osteoporotic fractures in primary health care in Catalonia (Spain): a population-based study". BMC Musculoskelet Disord 13: 79.

39. Prieto-Alhambra D, Avilés FF, Judge A, Van Staa T, Nogués X, et al. (2012 Burden of pelvis fracture: a population-based study of incidence, hospitalisation and mortality. Osteoporos Int 23: 2797-2803. 